\title{
International Experiences in the Operationalization of Culture for Military Operations - Field Research Results
}

\author{
Kamila Trochowska*
}

\begin{abstract}
The following article intends to summarize the conclusions and recommendations of research on the operationalization of culture for pre-deployment and operational training and activities. The results are based on research and interviews conducted by the author at Polish and foreign military institutions in the years 2009-2013, among others during study visits to international military institutions, US Army War College and multinational coalition forces representatives at US CENTCOM in 2012. This piece of research analyzes the solutions implemented in the preparation and conduct of operations by NATO (among others, Canada, the UK, Germany, Poland, and Turkey) and other armies (such as Australia, South Korea, Pakistan, Singapore, and Nepal).
\end{abstract}

Keywords: Operationalization of culture, cross-cultural competence, military operations, pre-deployment training.

Acknowledgements: This project was funded by the Polish National Science Center, grant no. DEC-2011/01/N/HS5/00981. The author would like to express her gratitude to all the multinational coalition representatives at US CENTCOM for their support.

\section{Introduction}

The emergence of population-centric operations has drawn attention to the need to consider the cultural factors of the Area of Operation. However, the missing link between the awareness of the cultural aspects of threats and the development of operational plans that take these aspects into consideration has not yet been found and fully utilized in military planning and conduct of operations. Due to the wide spectrum of cultural and social factors influencing the operational environment, the aforementioned operations gave priority to non-kinetic military activities, such as psychological operations (PSYOPS), information operations (INFO OPS), or the significance of civil-military coopera-

Kamila Trochowska, PhD, is a researcher and lecturer at the Institute of State Security of the Polish National Defense University in Warsaw. After an MA in cultural studies, she obtained her doctoral degree in security studies (PhD dissertation, Operationalization of Culture in Contemporary Military Operations). She currently runs two major national projects on the operationalization of culture for the Polish Armed Forces and National Science Center, in addition to her participation in projects on national and international security culture directed by the National Security Bureau, German Armed Forces and Swedish National Defense University. She conducted interdisciplinary field research at the Lakota Standing Rock Reservation in South Dakota, United States (2008), the Palestinian Yarmouk Refugee Camp in Damascus, Syria (2010), at Turkish police and military institutions (2011) and the US Army War College and US Central Command (2012). She is the author of numerous scientific publications about the cultural aspects of the contemporary security environment in Poland and abroad. 
tion components (CIMIC), which are based on a profound understanding of the cultural aspects of the reality in which they work.

Hence, contemporary operational success can be achieved only when the situational awareness of the operational environment is full and in-depth, as cultural awareness of the area of operation is a vital component of overall situational awareness. Therefore we face a need for the skill of operationalization of culture, understood as all the processes and skills involved in identifying the cultural features of any object of the activity (either the population in the Area of Operation [AOO], the Area of Responsibility [AOR], the "enemy," or Allied forces) vital to military activities paired with the integration of such knowledge and skills in planning, pre-deployment preparation, decision-making process, and general conduct of operations. It also includes the integration of universal cultural competence training into the overall career training development of officers. The general culture competence training has proven to be an optimal solution that enables the soldiers not only to adjust to the culturally "alien" operational environment, but also the more effective cooperation within multinational environments.

Thus, the aim of this article is to analyze the current status of the implementation of operationalization of culture in military operations in order to identify solutions, methods, and tools that can be used to design an improved model of operationalization of culture: one that would actually improve the efficiency of operations, as the analysis of American solutions demonstrated that not all serve their functions properly. ${ }^{1}$ Therefore, a critical review of guidelines and experiences in NATO and non-NATO countries was undertaken, including the experiences of Germany, Canada, the United Kingdom, the Netherlands, Italy, Turkey, Australia, Singapore, Romania, Thailand, Pakistan, Armenia, and Afghanistan.

\section{NATO's "Cultural Turn"}

Both the "cultural turn" of the U.S. Department of Defense and the deteriorating situation in Iraq and Afghanistan effected changes in NATO operational doctrines and solutions. They were summarized in the recommendations following Multinational Experiment 6 (MNE 6) that ended in 2010, particularly within goal 4.3, which focused on improving the efficiency of operations through the increase of cultural awareness of soldiers working in an operational environment that is "alien" in terms of traditions, social relations, way of life, and culture. As detailed in the initial report, Multinational Experiment 6 Baseline Assessment 2008 by USJFC, the basic cultural issues in the operational environment addressed in the edition of the MNE were primarily:

- Lack of ability to understand the dynamics of the operational environment in the social, cultural, political, legal, and economic aspects;

1 The analysis was performed by the author in "Operationalization of culture in population-centric operations - the American experience", paper presented at the ISMS Annual Conference Balancing domestic and international security requirements, International Society of Military Sciences, Royal Military College of Canada, Kingston, 23-24 October 2012, www.isofms.org/ cms_uploads/Trochowska_Abstract2012.pdf. 
- A negligible number of staff beyond the special forces trained in combating asymmetric threats and counterinsurgency operations (COIN) and educated in the issues of cultural awareness and cross-cultural communication;

- Lack of effective intercultural communication strategies;

- The diversity of the organizational cultures within the operational environment and problems with procedural and operational coordination between the different military, governmental and non-governmental organizations working in the area of operation;

- Joint forces and other interagency components must reach a common understanding of the operational environment;

- Commanders need comprehensive training in the competencies and capabilities of combined, international and other governmental organizations (OGA). ${ }^{2}$

After the NATO Bucharest summit of 2008, five key regions of Allied activities were set out that included planning, conduct, and coordination of military and nonmilitary tasks during operations; assessment of the environmental impact of operations and activities of civilians in the post-conflict reconstruction phase; consolidation, development, and the exchange of operational experiences between countries; training and educational programs to prepare for participation in operations; development of cooperation with international actors and organizations in the context of civil-military relations; and the issues of public diplomacy and the quality of stabilization and reconstruction during all phases of an operation. ${ }^{3}$

Aspects of multiculturalism in the collaboration of multinational and multiagency components were also explored during MNE 7 (2011-2012). Here, however, the focus was on effective intercultural cooperation in the security management of maritime, airspace, and cyberspace. ${ }^{4}$

MNE 6 was based on the comprehensive approach to effectively combating asymmetric opponents also through emphasis on social determinants of developments in the area of operations, cross-cultural awareness, and the enhancement of an integrated civilmilitary reconstruction process. The intended goals to be achieved by the sixth edition of MNE in relation to our terms were:

Goal 4. Common situational understanding of the operating environment.

4.1. Development of methods, processes, structures, personnel, and tools that enable the collection and analysis of information by multinational military components.

2 Francesco Pamplos and Jacinto Pena, eds., Cross-Cultural Awareness: Analytical Concept, MNE 6 Goal 4.3. Draft Version (Granada: TRADOC Directorate for Research, Doctrine and Materiel, January 2010), 18-19.

3 “Comprehensive Approach,” NATO A-Z, www.nato.int/cps/en/natolive/topics_51633.htm (25 October 2010).

4 “MNE 7: Access to Global Commons," 16 May 2011. 
4.2. Development of capacity and skills of the coalition forces, their international partners, government agencies, and NGOs to combat asymmetric threats and guerrilla warfare.

4.3. Development of a cross-cultural awareness concept for military operations and the use of cultural studies' tools to create training programs for the implementation of cross-cultural awareness among soldiers and commanders of the Allied forces.

4.4. Improvement of logistics in the ISAF operation.

4.5. Creation of an operational and strategic model of logistics management in the asymmetric threats environment. ${ }^{5}$

In essence, Goal 4.3. was a set of recommendations created on the basis of the best possible Allied solutions in the field of operationalization of culture for the purpose of military operations. They were summarized in three products of the goal, namely Guidelines for Commanders and Staffs: How to Engage with Local Societies During Military Operations; Guidelines for Commanders and Staffs: Operationalization Of Culture Into Military Operations (Best Practices), and Guidelines for Commanders and Staffs: How to Incorporate Cross Cultural Awareness into Syllabi/Curricula and Training Programs. ${ }^{6}$ The basis of the concepts and solutions was laid out in Operationalization of Culture into Military Operations, Best Practices. The solutions proposed in the publication are the concepts of training foreign officers and employing cultural advisers (CULADs), the use of Human Terrain Teams (HTTs), and the Red \& Green Teaming and Re-framing/Profiling actors' analysis method.

The concept of regional officers, cultural specialists or "foreign area officers" (FAO), and cultural advisors originated from the U.S. military. Such positions are usually attached to the Marine Expeditionary Force component or other units, depending on their geographical locations, where such officers serve as advisors to commanders on cultural matters. Their main roles are providing expertise in the integration of cultural factors in the planning and conduct of operations and assistance in predicting the secondary and tertiary effects of the operation on the local population and culture. ${ }^{7}$ Advisors also participate in exercises, simulations, conferences, and workshops to maintain an appropriate level of professionalism. Interestingly, the process of training lasts from two to five years for the FAO and ten years or more for CULADs. ${ }^{8}$ It includes in-depth education on the local culture, mainly in the form of living and working in the area.

HTTs - the second recommended concept - are based on the American concept with the same name, but due to several lessons learned during the original HTT activities,

5 Royal Norwegian Army, Multinational Experiment 6. Multimedia presentation. Oslo, 9 June 2009.

6 Multinational Experiment 6. Campaign Report. 4 February 2011, http://mne.oslo.mil.no:8080/Multinatio/MNE6produk/MNE6FinalR/file/MNE6\%20Final\%20 Report.pdf (11 October 2013).

7 Victor Bados, Operationalization of Culture into Military Operations: Best Practices (Granada: SP TRADOC, 2010), 13-14.

8 Ibid., p. 38. 
they have been modified. They still consist of five to nine-person teams with social sciences and operational backgrounds deployed by the Human Terrain System (HTS) to support field commanders by filling their cultural knowledge gap in the current operating environment and providing cultural interpretations of events occurring within their area of operations. Their goal is the same: to fill the cultural knowledge void by gathering ethnographic, economic, and cultural data about the $\mathrm{AOO}$ and provide databases and tools to support analysis and decision-making processes. The NATO-recommended HTTs, however, have a significantly more developed structure and support and are built on seven components or "pillars": HTTs, reach-back research cells, subject-matter expert networks, a tool kit, techniques, human terrain information, and specialized training. ${ }^{9}$ Their broader scope of research and reach-back support is intended to prevent the mistakes of the original American HTTs.

The final recommended solution is the Red \& Green Teaming and Re-framing/ Profiling actors' analysis method, a concept put forth by the Swedish Ministry of Defense, which is in principle a modified version of the aforementioned U.S. Army Red Teaming concept. The concept was developed to a point where it was possible to apply a method to generate all the involved actors' analyses in order to become more holistic and comprehensive and engulf the range of stakeholders that coalition forces must confront:

It could be defined as a method to understand the mindset of relevant actors in an area of operation and to contribute to the staff's learning of the Operational Environment: the Red \& Green teams give voice to the key actors in the operation and their main purpose is that of challenging Blue thinking. They discover hidden assumptions and mirror imaging. The method used by the Red \& Green teams (Profiling/reframing) focuses attention on seeking to understand the actors' frames of references in order to come closer to how they might think, what they might want, how they could interpret our actions, and how else we could interpret their beliefs and actions. As opposed to using Blue mindset and frames of reference to guess what other actors might think or do. This, in turn, lays a better ground for the development of potential Red or Green Course of Action. ${ }^{10}$

Having laid solid theoretical and doctrinal foundations, let us look at managing culture in military action in various countries.

\section{Operationalization of Culture in the British Army}

In NATO countries, operationalization of culture takes numerous forms, but apart from the UK, Germany, and Canada (and, of course, the U.S.), nowhere does it take the shape of an institutionalized system. In addition, the majority of the solutions are modeled on the American ones and hence the means of their implementation are similar. It is worthwhile to examine more closely several approaches and solutions in the countries with the most extensive experience in the field.

One such example is the British Army, which offers well-designed pre-deployment training in intercultural competencies. Among other factors, this is thanks to a long tradi-

\footnotetext{
9 Ibid., 14-15.

10 Ibid., 15.
} 
tion of multiculturalism within its own ranks and years of experience in conducting operations abroad. In addition to differences between individual citizens of the United Kingdom (and sometimes animosity, for example, among the soldiers of Scottish descent and the British ones), more significant cultural differences may occur. The British land forces consist of diverse national groups originating from various regions of the world, including Nepal with 3,400 people (most in the Brigade of Gurkhas), 2,000 from Fiji, more than 900 Jamaicans, 800 from South Africa and Ghana, and 600 from Zimbabwe. Other countries of British soldiers' origin also include the Seychelles, Mauritius, and Malta. $^{11}$

Therefore, the British Army stresses the promotion of intercultural understanding and, above all, respect as the basis of the soldiers' morale. As apparent in the basic doctrinal document regulating these issues, the British Army Cultural Guidance, respect for others is one of the British Army's core values. Respect lies at the very heart of fighting power and requires trust, cohesion, morale, and unit effectiveness. Respect is earned and respect is mutual. One cannot force another to respect them just as one cannot be forced to respect another. Respect is built on an understanding of other people, taking time to find out who they are, what their background may be and how that background affects how they think and act. ${ }^{12}$ The document also contains basic information about the aforementioned national groups that constitute the army, divided into categories of differences, similarities, hidden cultural patterns, and cultural differences that may pose the greatest problems in daily cooperation.

The British Army also includes the aforementioned Brigade of Gurkhas, composed of soldiers of Nepalese origin. Every year, out of more than 17,000 applicants, 230 are selected for training as snipers to serve within British Army ranks. The new arrivals' training includes 37 weeks of military and language preparation, of which two weeks are spent on cultural familiarization and integration, both in the theoretical and practical dimension. ${ }^{13}$ The first phase of cultural adjustment focuses on general orientation and the use of public transport. The second phase is dedicated to functioning in daily life and the third contributes to the continued improvement of everyday functioning in a culturally different environment, either in military or civilian aspects. Some of the knowledge developed during the preparation is later used during pre-deployment training.

Cultural preparation for functioning in various AOOs for the British contingents is well established for the majority of components that need it and is largely based on the US Marine pre-deployment solutions in this field. Pre-deployment training is obligatory for all troops; major attention, however, is paid to the preparation of the Defense Cultural Specialist Unit (DCSU). As of Afghanistan, its role was "to do what HTS does, and more: cultural awareness training for troops, and providing 'cultural specialists' to be deployed" (they appear to be, for the most part, linguists). The DCSU was involved in

11 Directorate of Educational and Training Services, British Army Cultural Guidance (Wiltshire, UK: Headquarters Land Forces, 2008), 2.

12 Ibid.

13 British Army. Ghurka Training "Cultural Orientation Programme," British Ministry of Defense, www.army.mod.uk/training_education/training/18265.aspx (11 February 2013). 
the recent failure, Operation Moshtarak, in the so-called "Marjah region." It is based at Royal Air Force Base Henlow and officially came into being in April 2009. Lieutenant Colonel Steven Windmill, from the defense ministry's Afghan specialist implementation team, set up the DCSU. The DCSU's "cultural advisors," deployed in Afghanistan, perform a mission very similar to that of HTS: "They help to identify and understand issues relating to the local cultural, political, economic, social and historical environment to help commanders make better and more informed decisions." There are twenty-five such individuals, assigned to senior military commanders, with the intention of increasing their number to forty. Each one speaks either Dari and/or Pashto."14 Nowadays, however, with the changes in training doctrine, the idea of incorporating cross-cultural competence into the lifelong professional development of the soldiers is emerging. ${ }^{15}$

\section{German Solutions}

In 2011 the Bundeswehr began a program of transformation and modernization that includes the incorporation of cross-cultural competence training in pre-deployment activities. The Central Command (Zentrum für Innere Führung) is responsible for cross-cultural matters, with the Center for Intercultural Competence in Koblenz as the research and coordination center. The survey on intercultural competence in the armed forces, performed on the twenty-second ISAF rotation in $2010,{ }^{16}$ provided valuable results to this field of activity of the armed forces. Among other findings, the following facts were established:

- Situations in which intercultural interactions create specific implications for the effectiveness of the armed forces are more common among personnel responsible for the security and training of the Afghan army and police, where $41 \%$ of respondents claimed to have had such contact daily and $42 \%$ indicated weekly encounters. For the rest of the component situation is as follows:

The commanding component had the smallest share in dealing with the local population, but this does not mean that intercultural skills are unnecessary for them. On the contrary, those responsible for major decisions need a broader range of skills to enable the creation of operational plans tailored to the socio-cultural reality of the AOO.

14 Maximilian Forte, "More European Press Coverage of the Human Terrain System," Zero Anthropology portal, 17 July 2010, http://zeroanthropology.net/2010/07/17/more-europeanpress-coverage-of-the-human-terrain-system (1 September 2013).

15 More about the training and solutions in Table 1.

16 Julius Hess, The Operational Relevance of Culture and the Effectiveness of Cross-Cultural Competence. Empirical Findings from a Panel Study among German Soldiers of the 22nd $I S A F$ contingent, multimedia presentation at the CIMIC Center of Excellence, Enschede, 2012. 


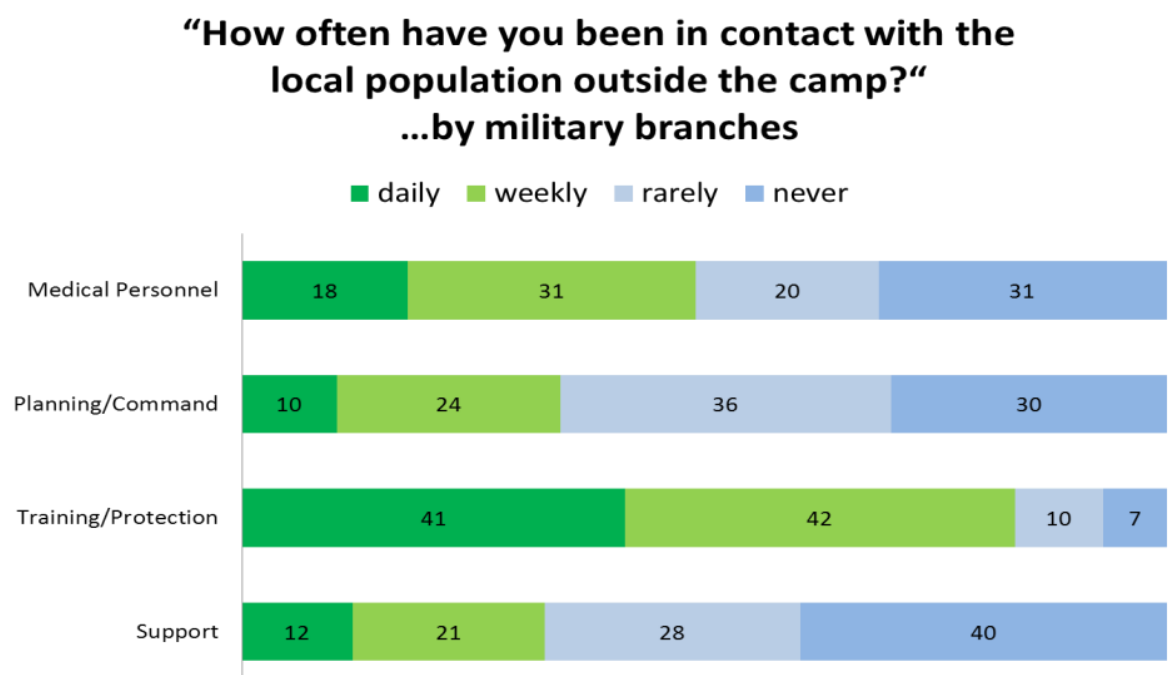

Chart 1: The frequency of soldiers' contact with the local population. ${ }^{17}$

- Intercultural interactions are important for security as misunderstandings can easily turn into violent conflicts. Still, the majority of respondents experienced events of a positive nature, with $46 \%$ having experienced minor verbal misunderstandings, and $34 \%$ were involved in serious conflicts with the local population. This remains an indication for an increased focus on multicultural issues, as indicated in Chart 2.

Intercultural competencies are mastered to varying degrees by soldiers at various levels of command, where the higher the rank, the higher the level of intercultural competence tends to be, as shown in Chart 3.

Remarkably, a number of soldiers gain the most knowledge and skills during operations, while the situation is reversed for higher-ranking officers. In their case we face a major abatement of the cross-cultural competence level in relation to the level achieved during training, which should be addressed in the design of pre-deployment training programs.

- Concerning the effect of cross-cultural competence in the conduct of operations, it was found that the appropriate level of intercultural skills has a significant impact on reducing misunderstandings with the local population. It also plays a significant role in resolving debates and major conflicts and decreases the levels of stress and uncertainty associated with the operation conducted in a foreign culture. ${ }^{18}$

17 Ibid.

18 Ibid. 


\section{"In the context of these contacts how often did the following occur?"}

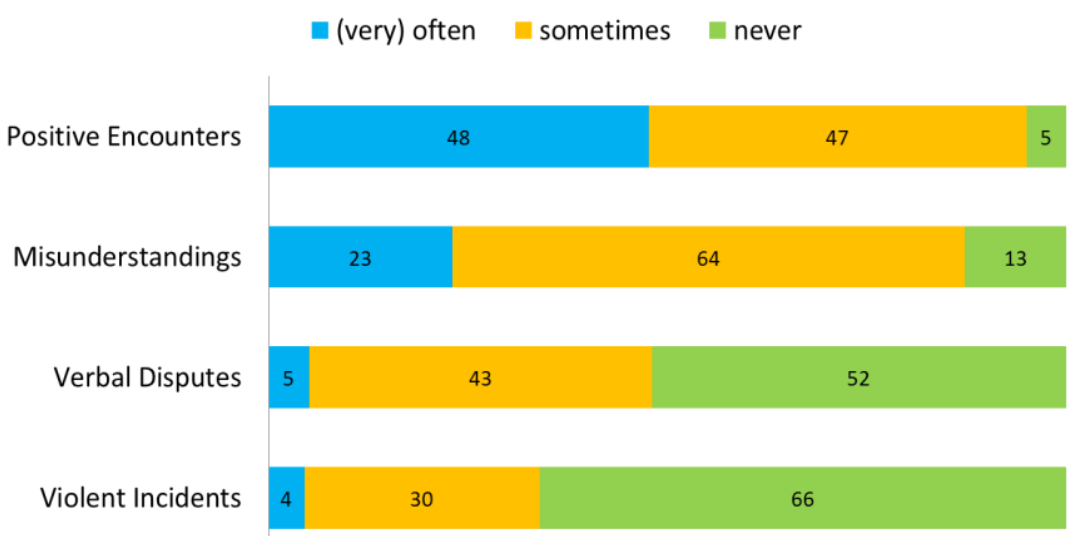

Chart 2: Cultural interactions with the local population. ${ }^{19}$

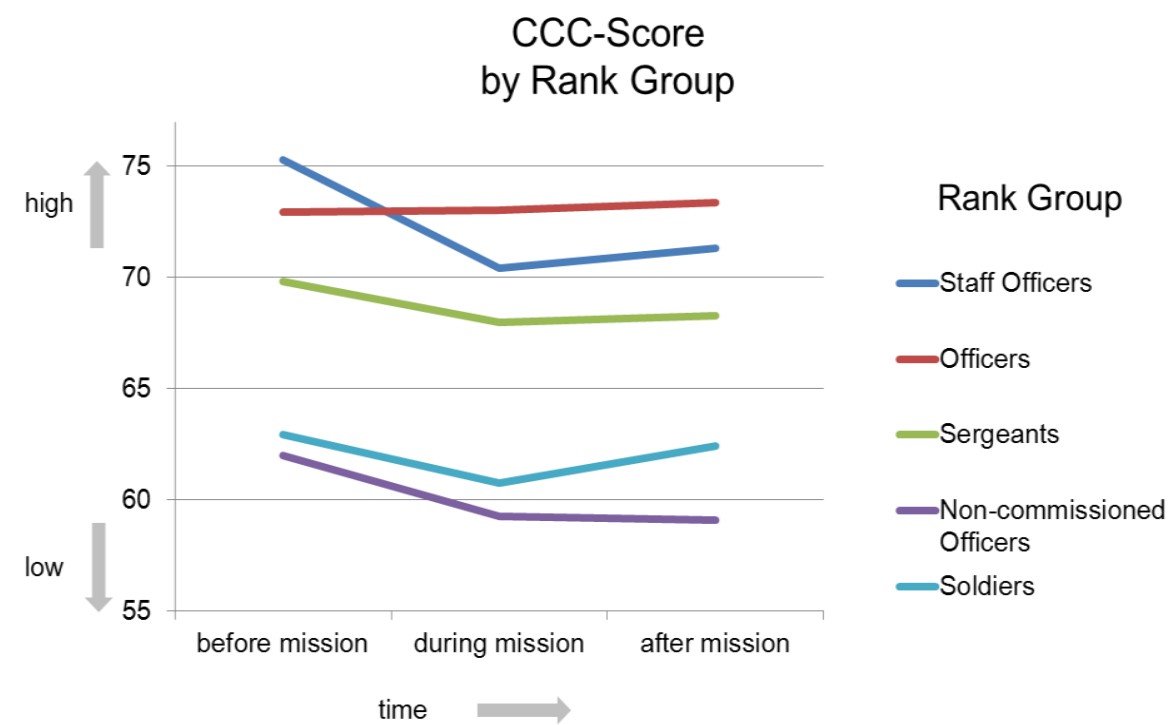

Chart 3: Intercultural competence training among soldiers of various ranks. ${ }^{20}$

19 Ibid.

20 Ibid. 
In light of these studies, the Bundeswehr has expanded the scope and methods of cross-cultural training conducted by both the center in Koblenz as well as individual units, as explained in Table 1 below. One type of tools used to improve the level of cross-cultural competence is, among others, study boards. Their aim is to develop both universal skills (resolving conflicts, ethic warfare) and regional cultural skills (ISAF and KFOR training boards). Each consists of six to ten large-format boards that lead the students through several discussions and problem-solving tasks during group work facilitated by a qualified instructor. An excerpt of the ISAF training board is displayed in Picture 1.

Currently, the Bundeswehr works on $3 \mathrm{C}$ distance learning courses and enhances the solutions in operationalization of culture within the framework of the annual international Coping with Culture workshop that involves institutions such as US TRADOC, the British defense ministry, the NATO CIMIC Center of Excellence in Enschede, and the Polish National Defense University.

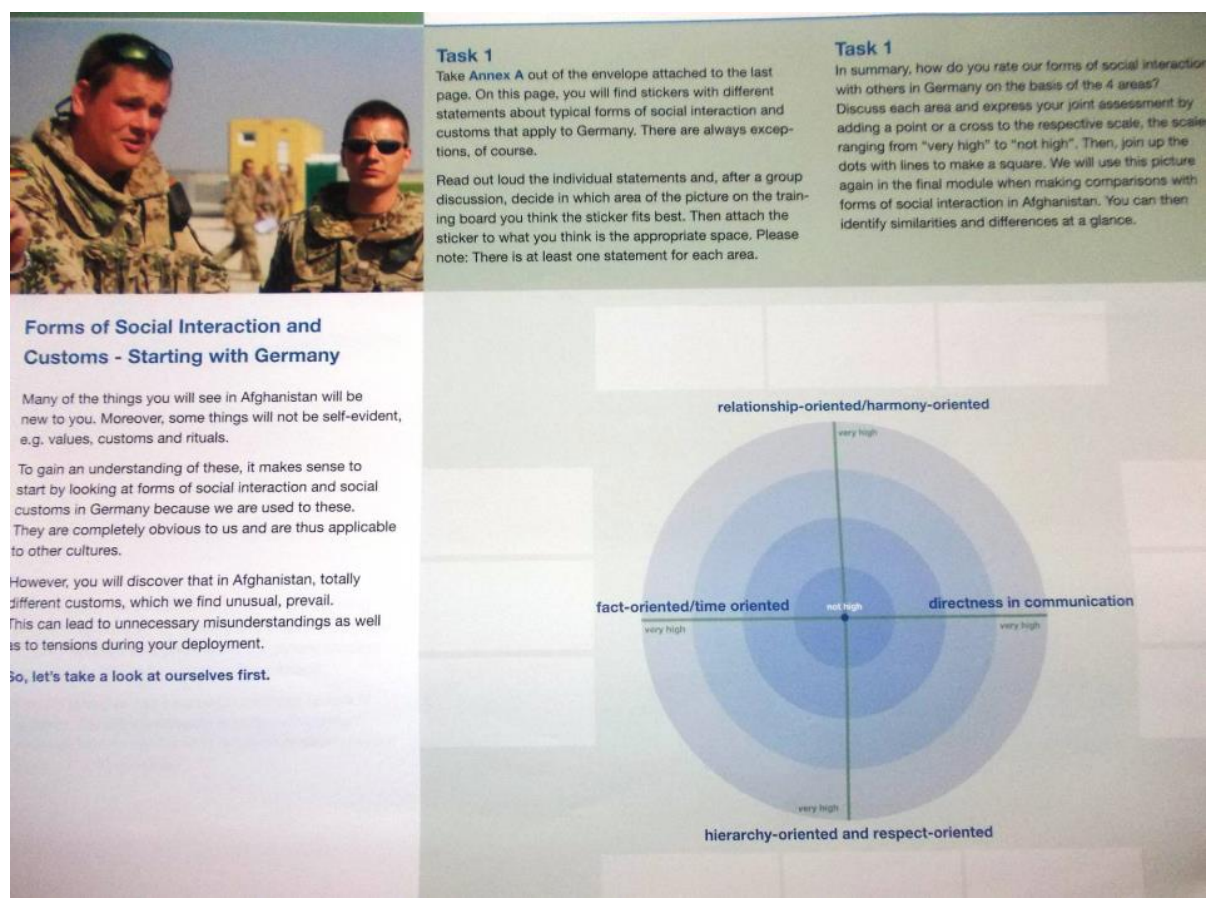

Picture 1: ISAF training board sample.

Source: Author's archives courtesy of Cross-cultural Competence Training Center: Koblenz, 2013. 


\section{Operationalization of Culture in Other NATO States}

Other NATO states implement various solutions in the field of operationalization of culture at different levels. A review of solutions in the land forces, as compared to the developed German and British solutions, is presented in Table 1 below. ${ }^{21}$

The table below compares various solutions in the field of operationalization of culture within select NATO states. In most countries, except the United Kingdom, Canada, and Germany, which are now beginning their programs, operationalization of culture is rather limited to preparations for the mission and the use of cultural advisors during the operation. Concerning the attempts to integrate cultural factors into the decision-making process, in none of the countries are such attempts reported and the development of intercultural competence in life-long vocational education and the training of commands and staffs, in addition to irregular initiatives, is not carried out in a systematic manner.

\section{Foreign Good Practices}

Concerning non-NATO states, the situation is no less varied and worth investigating. ${ }^{22}$ The interviews in this group were conducted with the military representatives of diverse countries such as Australia, South Korea, Nepal, El Salvador, Singapore, Romania, Armenia, and Thailand. In particular, the group includes both Australia and South Korea, whose solutions for operationalization of culture should be regarded as good practices in the field. ${ }^{23}$

Other countries, such as Romania or Thailand, present no less interesting ways of realizing the operationalization of culture schemes. Also Pakistani and Afghan representatives agreed to contribute to the survey, which added a valuable perspective on cultural training in the countries that are usually the subject of cultural education.

The aforementioned variety of solutions and experiences in the field of the operationalization of culture poses the question of the effectiveness of training. Is "the more the better" always true? For instance, although the United States has the most advanced training programs, the overall efficiency of its operations in Iraq and Afghanistan is not always as high as expected. On the other hand, the non-kinetic operations carried out by the Dutch component (where cultural training and deployment solutions are not as extensive) or Turkish stabilization activities (where there is virtually no training) have

21 The data were gathered from interviews conducted by the author with multinational coalition forces representatives (with experience in the operationalization of culture) during a study visit to the US CENTCOM in 2012, along with an overview of doctrines and other available documents. This part mainly summarized ISAF solutions. A full report about the research can be fund in Kamila Trochowska, Operationalization of Culture in Contemporary Military Operations, PhD dissertation (Warsaw: Polish National Defense University, 2013).

22 Data gathered from interviews (as described above), along with an overview of the doctrines and other available documents. This part mainly summarized peacekeeping operation solutions.

23 For details, see Zaytun Division, Civil-Military Operations Handbook, ROK Peace and Reconstruction Division, MND-NE Iraq, 2006. 
been judged favorably both by leaders and the local population. ${ }^{24}$ As research proves, the impact of cultural awareness on operational effectiveness depends on many factors, ranging from the time of year (during the winter months in Afghanistan, for instance, the number of attacks drops) to the ethnic composition, the security situation in a given $\mathrm{AOO}$, up to the cultural structure of the multinational military component that is responsible for a given region. With regard to the last factor, it might seem that the experience of living in a multicultural society expedites cultural familiarization. It depends, however, on the type of multicultural society one comes from. For example, the American multiculturalism model is more "caste-like" and aims at providing a common cultural framework for all. This makes it more difficult for the soldiers to function in a culturally foreign area than it is for, say, Dutch and Australian soldiers who come from more flexible and egalitarian societies.

\section{Conclusion}

In light of the aforementioned considerations about the multitude of doctrinal and potentially effective solutions, the question of their operational effectiveness arises. A perfect case study in this respect is provided by ISAF's "Hearts and Minds" operation. ${ }^{25}$ On the one hand, many innovative operational initiatives undertaken within its framework were successful. On the other, as indicated by one of the interviewees (an Afghan major working for the Directorate of Religious and Cultural Affairs), much of the good has been destroyed within a short time, as

ISAF forces still lack a lot of cultural sensitivity, skills and knowledge when dealing with local population. They get perfect training in theory, and then they come to us and break all the rules as if they have forgotten. A major problem is the American forces' lack of respect for religion (less so in the case of Europeans). Bombarding mosques, interfering with weddings, burning the Quran - those are incidents, but they completely undermine the trust of the local people and destroy what good has been done. Therefore, the people turn to the Taliban. ${ }^{26}$

PSYOPS products that aim at boosting the popularity of Allied forces among Afghan society, such as the Sada-e-Azadi (Voice of Freedom) newspaper and radio station, or propaganda videos or billboards, do not much alter the situation. ${ }^{27}$

24 Oskari Eronen, PRT Models in Afghanistan. Approaches to Civil-Military Integration (Kuopio: Crisis Management Center Finland, 2008), 45, available at www.cmcfinland.fi/ download/41858_Studies_5_Eronen.pdf.

25 The author avoids using the "hearts and minds" rationale since she believes that "winning hearts and minds" pertains more to the medical sciences, especially transplantology.

${ }^{26}$ For the source cf. reference 21.

27 Official website of the ISAF Sada-e-Azadi radio station and newspaper, http://sada-e-azadi.net (21 March 2013). 
Table 1: Solutions in operationalization of culture within select NATO countries. ${ }^{1}$

\begin{tabular}{|c|c|c|c|c|c|c|}
\hline & Germany & Canada & UK & Netherlands & Italy & Turkey \\
\hline $\begin{array}{l}\text { Average } \\
\text { length of } \\
\text { cultural pre- } \\
\text { deployment } \\
\text { training }\end{array}$ & 2 weeks & $\begin{array}{l}6 \text { weeks of general } \\
\text { training that in- } \\
\text { cludes elements of } \\
3 \mathrm{C}\end{array}$ & $\begin{array}{l}\text { Depending on the } \\
\text { unit and specializa- } \\
\text { tion, from one week } \\
\text { to several (for the } \\
\text { DCSU) }\end{array}$ & $\begin{array}{l}\text { Several days } \\
\text { during pre- } \\
\text { deployment } \\
\text { training }\end{array}$ & $\begin{array}{l}\text { Several days } \\
\text { during pre- } \\
\text { deployment } \\
\text { training }\end{array}$ & $\begin{array}{l}\text { No institutional- } \\
\text { ized training; } \\
\text { units carry out } \\
\text { such training if } \\
\text { needed on their } \\
\text { own }\end{array}$ \\
\hline $\begin{array}{l}\text { Organiza- } \\
\text { tion of } \\
\text { training. } \\
\text { Forms and } \\
\text { methods }\end{array}$ & $\begin{array}{l}\text { Center for Inter- } \\
\text { cultural Compe- } \\
\text { tence in Koblenz } \\
\text { provides training } \\
\text { boards and in- } \\
\text { structors for pre- } \\
\text { deployment exer- } \\
\text { cises and country } \\
\text { studies publica- } \\
\text { tions. }\end{array}$ & $\begin{array}{l}\text { Peace Support } \\
\text { Training Center } \\
\text { conducts most train- } \\
\text { ing programs. Their } \\
\text { scope depends on } \\
\text { the mission, rank } \\
\text { and position of the } \\
\text { training unit/ indi- } \\
\text { viduals. Soldiers are } \\
\text { usually trained in } \\
\text { the basic rules of } \\
\text { conduct in a foreign } \\
\text { cultural environ- } \\
\text { ment. A wider range } \\
\text { of training covering } \\
\text { the history, customs } \\
\text { and simulation is } \\
\text { mandated to higher } \\
\text { rank soldiers. Part of }\end{array}$ & $\begin{array}{l}\text { Pre-deployment } \\
\text { training is obliga- } \\
\text { tory for all. Major } \\
\text { focus is put to } \\
\text { Defense Cultural } \\
\text { Specialist Unit, } \\
\text { however with the } \\
\text { change of doctrine, } \\
\text { the integration of } \\
\text { cross-cultural com- } \\
\text { petence training in } \\
\text { overall career devel- } \\
\text { opment is being in- } \\
\text { troduced. Pre-de- } \\
\text { ployment training is } \\
\text { realized in the form } \\
\text { of practical exer- } \\
\text { cises that focus on } \\
\text { both universal and }\end{array}$ & $\begin{array}{l}\text { 3C training is a } \\
\text { several-hour } \\
\text { part of a four- } \\
\text { week pre- } \\
\text { deployment } \\
\text { training in the } \\
\text { field of history, } \\
\text { culture and cus- } \\
\text { toms of the fu- } \\
\text { ture AOO. }\end{array}$ & $\begin{array}{l}\text { There is no in- } \\
\text { stitutionalized } \\
\text { training. Each } \\
\text { branch of the } \\
\text { armed forces } \\
\text { and even each } \\
\text { individual unit } \\
\text { prepares itself in } \\
\text { this regard. } \\
\text { Generally, a unit } \\
\text { learns about the } \\
\text { geo-political } \\
\text { conditions, } \\
\text { cross-cultural } \\
\text { diversity and } \\
\text { proper modes of } \\
\text { behavior in for- } \\
\text { eign cultural } \\
\text { AOO. }\end{array}$ & $\begin{array}{l}\text { Mainly officers } \\
\text { training in the } \\
\text { cultural aspects } \\
\text { of the area of } \\
\text { operation is } \\
\text { conducted, usu- } \\
\text { ally based on } \\
\text { literature and } \\
\text { reports prepared } \\
\text { by soldiers re- } \\
\text { turning from a } \\
\text { mission. }\end{array}$ \\
\hline
\end{tabular}

1 Source: Own elaboration on the basis of interviews conducted by the author. For details see Kamila Trochowska, Operationationalization of culture in contemporary military operations (Warsaw: Polish National Defense University, 2013). 


\begin{tabular}{|c|c|c|c|c|c|c|}
\hline 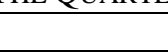 & Germany & Canada & UK & Netherlands & Italy & Turkey \\
\hline & & $\begin{array}{l}\text { intercultural training } \\
\text { is conducted in "Af- } \\
\text { ghan villages" } \\
\text { (training facilities } \\
\text { modeled on a sam- } \\
\text { ple Afghan village } \\
\text { to provide a most re- } \\
\text { alistic training envi- } \\
\text { ronment. }\end{array}$ & $\begin{array}{l}\text { regional intercul- } \\
\text { tural competence. } \\
\text { Teaching tools } \\
\text { include computer } \\
\text { programs and } \\
\text { distance learning } \\
\text { systems such as } \\
\text { ADL courses. }{ }^{2} \text { The } \\
\text { training is also con- } \\
\text { tracted to a civilian } \\
\text { company. }\end{array}$ & & & \\
\hline $\begin{array}{l}\text { Using for- } \\
\text { eign solu- } \\
\text { tions in op- } \\
\text { erationaliza- } \\
\text { tion of cul- } \\
\text { ture }\end{array}$ & $\begin{array}{l}\text { Own program } \\
\text { built on the basis } \\
\text { of NATO stan- } \\
\text { dards. Female En- } \\
\text { gagement Teams } \\
\text { (FETs) as a sup- } \\
\text { port to several } \\
\text { units. }\end{array}$ & $\begin{array}{l}\text { British solutions } \\
\text { and employment of } \\
\text { their instructors. } \\
\text { The use of White } \\
\text { Teams modeled on } \\
\text { Human Terrain } \\
\text { Teams (HTTs). }\end{array}$ & $\begin{array}{l}\text { The concept of } \\
\text { FETs, data gather- } \\
\text { ing methods by the } \\
\text { DCSU based on the } \\
\text { ones used by HTTs. }\end{array}$ & $\begin{array}{l}\text { The FETs con- } \\
\text { cept. }\end{array}$ & $\begin{array}{l}\text { Exercises run by } \\
\text { foreign experts } \\
\text { according to the } \\
\text { needs. }\end{array}$ & None \\
\hline
\end{tabular}

2 A sample British Army ADL course, Cultural Awareness Afghanistan Course, can be found at www.adl.aon.edu.pl/pl/kursy/kursy-adl/17cultural-awareness-afghanistan-course (11 August 2012).

3 For example, the British contractor TQ. For a sample training plan see www.tq.com/filelib/OPTAG-Case-Study.pdf (11 August 2012).

4 Female Engagement Teams are a concept introduced by the U.S. Army in Afghanistan. For more about their organization and functioning cf. the Center for Army's Lessons Learned, Commander's Guide to Female Engagement Teams. Handbook (Kansas: CALL, 2011), 11-28.

5 Maximilian Forte, "Canada's Own Human Terrain System: White Situational Awareness Team in Afghanistan," Zero Anthropology, 12 April 2008, http://zeroanthropology.net/2008/11/24/canadas-own-human-terrain-system-white-situational-awareness-team-in-afghanistan/ (12 September 2013). 
SUMMER 2014

\begin{tabular}{|c|c|c|c|c|c|c|}
\hline & Germany & Canada & UK & Netherlands & Italy & Turkey \\
\hline $\begin{array}{l}\text { Are cultural } \\
\text { advisors to } \\
\text { the com- } \\
\text { mander em- } \\
\text { ployed in } \\
\text { the AOO? }\end{array}$ & Yes & Yes & Yes & No & Yes & $\mathrm{No}^{6}$ \\
\hline $\begin{array}{l}\text { What are the } \\
\text { field solu- } \\
\text { tions in op- } \\
\text { eraitonaliza- } \\
\text { tion of cul- } \\
\text { ture? }\end{array}$ & $\begin{array}{l}\text { FETs, cultural ad- } \\
\text { visors }\end{array}$ & $\begin{array}{l}\text { Cultural advisors, } \\
\text { interpreters, White } \\
\text { Teams }\end{array}$ & $\begin{array}{l}\text { Defense Cultural } \\
\text { Specialist Unit, } \\
\text { FETs }\end{array}$ & $\begin{array}{l}\text { FETs, transla- } \\
\text { tors advising on } \\
\text { cultural matters }\end{array}$ & $\begin{array}{l}\text { A place for dis- } \\
\text { cussions on the } \\
\text { most burning } \\
\text { cultural issues } \\
\text { during briefings }\end{array}$ & $\begin{array}{l}\text { None institu- } \\
\text { tionalized }\end{array}$ \\
\hline $\begin{array}{l}\text { Is there a } \\
\text { system of } \\
\text { feedback, } \\
\text { assessment } \\
\text { and lessons } \\
\text { learned in } \\
\text { the field of } \\
\text { culture and } \\
\text { 3C training? }\end{array}$ & $\begin{array}{l}\text { Yes, on a lessons- } \\
\text { learned basis }\end{array}$ & $\begin{array}{l}\text { A lessons-learned } \\
\text { basis and post-de- } \\
\text { ployment feedback. } \\
\text { Training programs } \\
\text { are updated after } \\
\text { every deployment. }\end{array}$ & $\begin{array}{l}\text { Yes, an organized } \\
\text { system of gathering } \\
\text { experiences on a } \\
\text { lessons-learned } \\
\text { basis }\end{array}$ & $\begin{array}{l}\text { Yes, on a } \\
\text { lessons-learned } \\
\text { basis }\end{array}$ & $\begin{array}{l}\text { Yes, a system of } \\
\text { operational as- } \\
\text { sessment on a } \\
\text { lessons-learned } \\
\text { basis }\end{array}$ & $\begin{array}{l}\text { On a lessons- } \\
\text { learned basis }\end{array}$ \\
\hline
\end{tabular}

6 The respondents indicated that advisors were not considered necessary since cultural differences between Turkey and Afghanistan were not an issue. 
THE QUARTERLY JOURNAL

Table 2: Solutions in operationalization of culture in non-NATO countries (1).

\begin{tabular}{|c|c|c|c|c|c|}
\hline & Australia & South Korea & EI Salvador & Nepal & Singapore \\
\hline $\begin{array}{l}\text { Average cultural } \\
\text { pre-deployment } \\
\text { training length }\end{array}$ & $\begin{array}{l}\text { Depending on the } \\
\text { position, from a few } \\
\text { hours (for example } \\
\text { logistics) to one year } \\
\text { (intel specialists). }\end{array}$ & $\begin{array}{l}\text { As part of the overall } \\
\text { preparation for the } \\
\text { operation from one } \\
\text { to eight weeks, de- } \\
\text { pending on the posi- } \\
\text { tion. }\end{array}$ & $\begin{array}{l}\text { Several hours as part } \\
\text { of a general pre-de- } \\
\text { ployment training, } \\
\text { content depending } \\
\text { on the position. }\end{array}$ & $\begin{array}{l}\text { A few hours up to a } \\
\text { several days as part } \\
\text { of pre-deployment } \\
\text { training, depending } \\
\text { on the position. }\end{array}$ & No answer \\
\hline $\begin{array}{l}\text { Organization of } \\
\text { training. Forms } \\
\text { and methods }\end{array}$ & $\begin{array}{l}\text { Typically, as part of } \\
\text { the pre-deployment } \\
\text { training conducted } \\
\text { by the unit. Lack of a } \\
\text { formalized program } \\
\text { for the Army and } \\
\text { other armed forces. } \\
\text { Reconnaissance spe- } \\
\text { cialists subject to a } \\
\text { year of cultural train- } \\
\text { ing in the target } \\
\text { country. }\end{array}$ & $\begin{array}{l}\text { Training consists of } \\
\text { sequenced modules: } \\
\text { general cross-cul- } \\
\text { tural competencies } \\
\text { for all, basic rules of } \\
\text { conduct in a particu- } \\
\text { lar culture, cultural } \\
\text { aspects of the proce- } \\
\text { dures at the opera- } \\
\text { tional level, the prin- } \\
\text { ciple of co-operation } \\
\text { with cultural special- } \\
\text { ists and the appropri- } \\
\text { ate language train- } \\
\text { ing. }\end{array}$ & $\begin{array}{l}\text { Mainly the United } \\
\text { Nations Training } \\
\text { Package for Peace- } \\
\text { keepers on Cultural } \\
\text { Awareness is used. } \\
\text { During the training, } \\
\text { basic information } \\
\text { about the culture of } \\
\text { the future AOO, } \\
\text { some skills enabling } \\
\text { cross-cultural com- } \\
\text { munication and rules } \\
\text { of correct behavior } \\
\text { in a given culture are } \\
\text { taught. }\end{array}$ & $\begin{array}{l}\text { Depends on the op- } \\
\text { eration and should } \\
\text { be realized in } \\
\text { individual units. In } \\
\text { reality, it is limited } \\
\text { to basic socio-cul- } \\
\text { tural information and } \\
\text { the etiquette of a } \\
\text { given AOO. }\end{array}$ & $\begin{array}{l}\text { It forms part of the } \\
\text { pre-deployment } \\
\text { training realized in a } \\
\text { basic form of re- } \\
\text { gional competence } \\
\text { training. }\end{array}$ \\
\hline $\begin{array}{l}\text { Using foreign so- } \\
\text { lutions in opera- } \\
\text { tionalization of } \\
\text { culture }\end{array}$ & $\mathrm{No}$ & $\begin{array}{l}\text { Yes, mainly Ameri- } \\
\text { can ones }\end{array}$ & $\begin{array}{l}\text { Yes, United Nations } \\
\text { Training Package } \\
\text { for Peacekeepers on } \\
\text { Cultural Awareness }\end{array}$ & $\mathrm{No}$ & $\begin{array}{l}\text { Yes, Red Teaming } \\
\text { and some solutions } \\
\text { of the Human Ter- } \\
\text { rain System }\end{array}$ \\
\hline
\end{tabular}


SUMMER 2014

\begin{tabular}{|c|c|c|c|c|c|}
\hline & Australia & South Korea & El Salvador & Nepal & Singapore \\
\hline $\begin{array}{l}\text { Are cultural advi- } \\
\text { sors to the com- } \\
\text { mander employed } \\
\text { in the AOO? }\end{array}$ & Yes & No & No & Yes & Yes \\
\hline $\begin{array}{l}\text { What are the field } \\
\text { solutions in } \\
\text { operationalization } \\
\text { of culture? }\end{array}$ & $\begin{array}{l}\text { Working closely } \\
\text { with local communi- } \\
\text { ties and respect for } \\
\text { the customs in the } \\
\text { AOO (e.g. Afghani- } \\
\text { stan: women perform } \\
\text { searches on women, } \\
\text { all decisions follow a } \\
\text { consultation with the } \\
\text { elders if possible). }\end{array}$ & $\begin{array}{l}\text { The emphasis is on } \\
\text { ensuring good coop- } \\
\text { eration and friend- } \\
\text { ship with the local } \\
\text { population. It is also } \\
\text { important to facili- } \\
\text { tate understanding of } \\
\text { Koreans and their } \\
\text { culture through } \\
\text { initiatives such as } \\
\text { the organization of a } \\
\text { Korean culture day, } \\
\text { and, if security } \\
\text { conditions allow it, } \\
\text { football matches, or } \\
\text { taekwondo classes. }\end{array}$ & $\begin{array}{l}\text { Depending on the } \\
\text { needs of the opera- } \\
\text { tion, the activities, } \\
\text { tools, and means are } \\
\text { chosen. }\end{array}$ & $\begin{array}{l}\text { Respect for the cul- } \\
\text { ture of the AOO and } \\
\text { its rules. Cultural ad- } \\
\text { visors to the com- } \\
\text { mander and attention } \\
\text { to proper media im- } \\
\text { age as support. }\end{array}$ & No answer. \\
\hline $\begin{array}{l}\text { Is there a system } \\
\text { of feedback, as- } \\
\text { sessment and } \\
\text { lessons learned in } \\
\text { the field of culture } \\
\text { and 3C training? }\end{array}$ & $\begin{array}{l}\text { Yes, an organized } \\
\text { assessment system: } \\
\text { surveys after each } \\
\text { rotation and a "les- } \\
\text { sons learned" base }\end{array}$ & $\begin{array}{l}\text { Yes, an organized } \\
\text { system of assessment } \\
\text { and a "lessons } \\
\text { learned" base }\end{array}$ & $\begin{array}{l}\text { Yes, an organized } \\
\text { system of assessment } \\
\text { based on surveys (ir- } \\
\text { regular) and a "les- } \\
\text { sons learned" base }\end{array}$ & $\begin{array}{l}\text { Yes, a "lessons } \\
\text { learned" base }\end{array}$ & $\begin{array}{l}\text { Yes, an organized } \\
\text { system of assessment } \\
\text { and a "lessons } \\
\text { learned" base }\end{array}$ \\
\hline
\end{tabular}


THE QUARTERLY JOURNAL

Table 3: Solutions in operationalization of culture in non-NATO countries (2).

\begin{tabular}{|c|c|c|c|c|c|}
\hline & Romania & Armenia & Thailand & Pakistan & Afghanistan \\
\hline $\begin{array}{l}\text { Average cultural } \\
\text { pre-deployment } \\
\text { training length and } \\
\text { form }\end{array}$ & $\begin{array}{l}\text { One day in } 3 \text { months } \\
\text { of overall training }\end{array}$ & $\begin{array}{l}\text { A few hours up to a } \\
\text { few days depending } \\
\text { on the position, but } \\
\text { it is obligatory for } \\
\text { all the forces de- } \\
\text { ployed }\end{array}$ & No answer & $\begin{array}{l}\text { None. } \\
\text { Religious and cul- } \\
\text { tural similarities to } \\
\text { the AOO makes it } \\
\text { unnecessary. }\end{array}$ & $\begin{array}{l}\text { The Directorate of } \\
\text { Religious and Cul- } \\
\text { tural Affairs is the } \\
\text { institution responsi- } \\
\text { ble for improvement } \\
\text { of cultural aware- } \\
\text { ness among the gov- } \\
\text { ernmental and mili- } \\
\text { tary structures and } \\
\text { the local population. }\end{array}$ \\
\hline $\begin{array}{l}\text { Organization of } \\
\text { training. Forms and } \\
\text { methods }\end{array}$ & $\begin{array}{l}\text { The entire unit/ } \\
\text { detachment to be } \\
\text { deployed follows a } \\
\text { specific program of } \\
\text { cultural awareness } \\
\text { through different } \\
\text { courses (1-3 } \\
\text { months). }\end{array}$ & $\begin{array}{l}\text { Briefings in peace- } \\
\text { keeping brigade for } \\
\text { the entire deployed } \\
\text { personnel, then fa- } \\
\text { miliarization with } \\
\text { the culture of coun- } \\
\text { tries in which the } \\
\text { army will be de- } \\
\text { ployed. }\end{array}$ & $\begin{array}{l}\text { An instructor is in- } \\
\text { vited to brief the } \\
\text { troops. A training on } \\
\text { cultural issues that } \\
\text { are important to the } \\
\text { unit is conducted, } \\
\text { for example on how } \\
\text { to perform a body } \\
\text { search in a different } \\
\text { culture. }\end{array}$ & $\begin{array}{l}\text { During the pre-de- } \\
\text { ployment training, } \\
\text { the focus is mainly } \\
\text { on negotiation as a } \\
\text { prerequisite of suc- } \\
\text { cess. }\end{array}$ & $\begin{array}{l}\text { Everyday coopera- } \\
\text { tion with American } \\
\text { or other forces train- } \\
\text { ing us is a kind of } \\
\text { cultural training it- } \\
\text { self. }\end{array}$ \\
\hline $\begin{array}{l}\text { Using foreign solu- } \\
\text { tions in operation- } \\
\text { alization of culture }\end{array}$ & No & $\begin{array}{l}\text { No. Other Armenian } \\
\text { Army units use the } \\
\text { American ones. }\end{array}$ & $\begin{array}{l}\text { United Nations, in } \\
\text { particular Indone- } \\
\text { sian experiences. }\end{array}$ & No & $\begin{array}{l}\text { Yes. The Americans } \\
\text { and other ISAF na- } \\
\text { tions train us and we } \\
\text { apply their solu- } \\
\text { tions. }\end{array}$ \\
\hline
\end{tabular}


SUMMER 2014

\begin{tabular}{|c|c|c|c|c|c|}
\hline $\begin{array}{l}\text { Are cultural advi- } \\
\text { sors to the com- } \\
\text { mander employed in } \\
\text { the AOO? }\end{array}$ & No & No & No & No & Yes \\
\hline $\begin{array}{l}\text { What are the field } \\
\text { solutions in opera- } \\
\text { tionalization of cul- } \\
\text { ture? }\end{array}$ & $\begin{array}{l}\text { Using interpreters' } \\
\text { experience. } \\
\text { Cooperating with } \\
\text { and using the } \\
\text { experiences of other } \\
\text { deployed contin- } \\
\text { gents. }\end{array}$ & $\begin{array}{l}\text { Soldiers learn from } \\
\text { their predecessors } \\
\text { (no specific group) }\end{array}$ & No answer & Civil Affairs unit & $\begin{array}{l}\text { The Directorate of } \\
\text { Religious and Cul- } \\
\text { tural Affairs has } \\
\text { advisors for every } \\
\text { unit (Religious and } \\
\text { Cultural Affairs } \\
\text { Officers). }\end{array}$ \\
\hline $\begin{array}{l}\text { Is there a system of } \\
\text { feedback, assess- } \\
\text { ment and lessons } \\
\text { learned in the field } \\
\text { of culture and 3C } \\
\text { training? }\end{array}$ & $\begin{array}{l}\text { Yes. Surveys after } \\
\text { service and a "les- } \\
\text { sons learned" base. }\end{array}$ & No & $\begin{array}{l}\text { Yes. Surveys dur- } \\
\text { ing/after service } \\
\text { abroad. "Lessons } \\
\text { learned" base. }\end{array}$ & No & $\begin{array}{l}\text { Yes, collected by } \\
\text { Afghan "Lessons } \\
\text { Learned" Center. }\end{array}$ \\
\hline
\end{tabular}




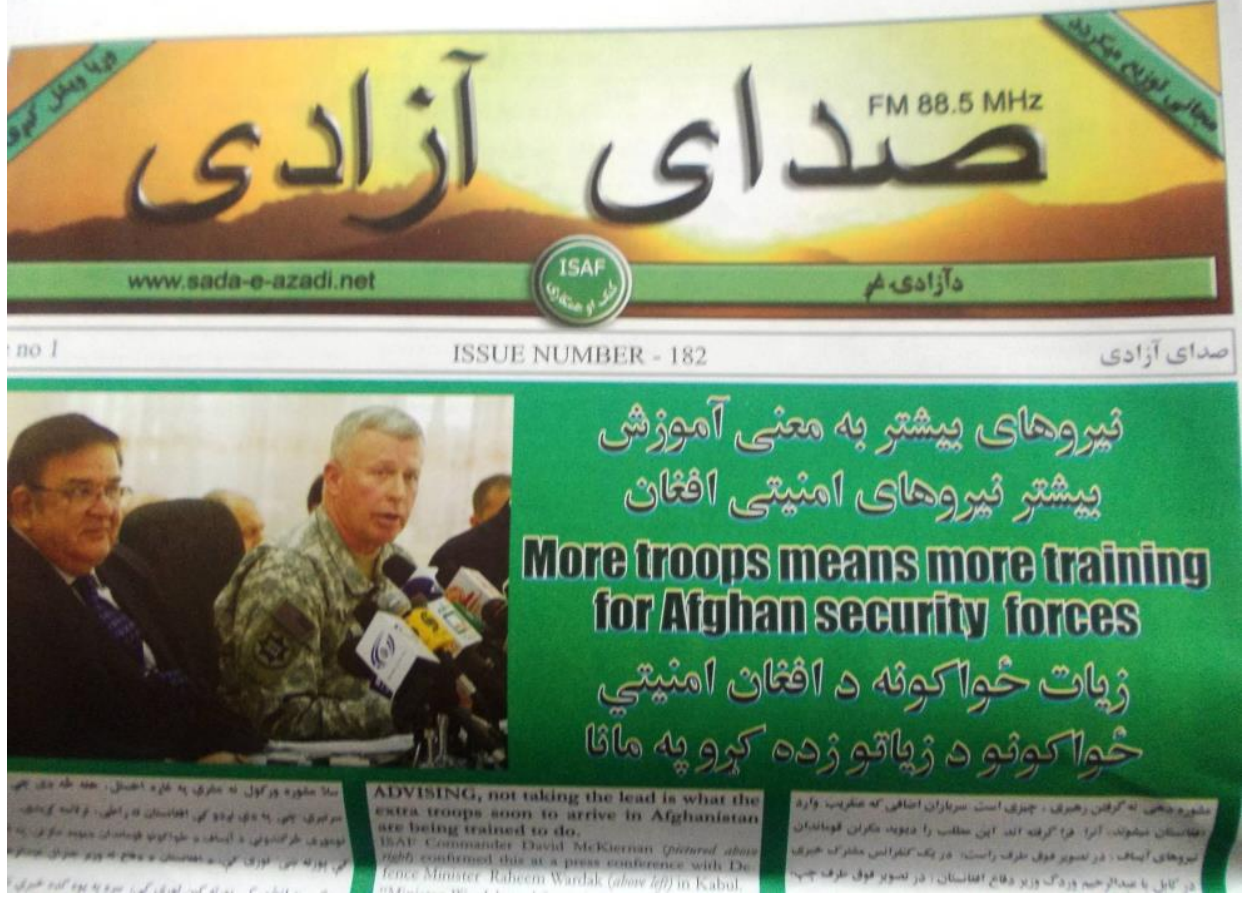

Picture 2: ISAF's Sada-e-Azadi newspaper (Source: from the author's archive).

A further indicator of the effectiveness of the troops' cultural competence may be the degree to which the objectives of an operation have been achieved. In the case of ISAF, the situation is unsatisfactory when we look at the assessment made by ISAF and Afghan governmental and non-governmental organizations. The majority of efforts to provide security, support the reconstruction and development processes, and provide full legitimacy to the government failed. Those assessments are reflected in both official summaries $^{1}$ and in Afghan opinion polls. It is difficult to argue otherwise when fewer and fewer respondents consider the current situation in Afghanistan better than in 2001, before the fall of the Taliban regime ( $41 \%$ of respondents believe that their families do better, but as many as $50 \%$ say that the situation is similar or worse). In addition, one third of society is not satisfied with their situation, and $40 \%$ are dissatisfied with the

1 Anthony Cordesman, The Afghanistan-Pakistan War at the End of 2011: Strategic Failure? Talk Without Hope? Tactical Success? Spend Not Build (And Then Stop Spending)? (Washington: Center for Strategic and International Studies, 2011). 
direction in which the changes in Afghanistan appear to be leading. ${ }^{2}$ To a large extent, what contributed to a partial failure of the realization of strategic goals was the underestimation of cultural factors at the strategic level, such as the nature of Afghan society, its primary needs after the violent change of the political system, and the need for adjusting the democracy to the people, and not the other way around. But the lack of proper preparation to set realistic goals in a culturally different environment is a different story and would neccessitate another article.

In most of the armies described in the present article (except the United Kingdom, Canada, and Germany), the operationalization of culture is limited to a few hours of training during the pre-deployment preparation for the mission, and to the use of cultural advisors during the operation. In such circumstances, it is rather difficult to realize the full potential of the operationalization of culture, which comprises all the processes and skills involved in the identification of aspects of the culture that are vital for military activities (either the AOO/AOR population, the "enemy" or Allied forces) and the integration of such knowledge and skills in the planning, pre-deployment preparation, decision-making process, and general conduct of operations. Moreover, trainings involving universal cultural skills that would expedite the process of acculturation and the gaining of regional knowledge during the vocational education of soldiers, commands, staff, and reserve officers are not carried out in a systematic manner in any of the countries under consideration. Pre-deployment training in regional knowledge, rather than skills, are mandatory in the majority of armies; however, they are usually limited to a few hours of lectures on basic aspects of the AOO culture. Only in some countries is the lecture system supplemented by seminars, discussions, simulation games, role-playing, distance learning, and multimedia support. The situation should be changed because cross-cultural competence embraces a set of interdisciplinary skills that cannot be developed by simply attending lectures.

In short, our search for an effective solution in this field does not aim at creating an army of passionate anthropologists or ethnographers. We seek a set of skills, attitudes, and knowledge that is adequate for the level of operation, rank, and function, and that is capable of enhancing operational effectiveness in a culturally different and diverse environment. Military culture is regarded as one of the most rigid structures, with very specific tasks that may sometimes contradict the rules and demands of genuine crosscultural competence. Yet, for all the differences on the surface, under each uniform there is a human being who belongs to one human family. Soldiers should never forget that.

2 "Afghanistan Index: Tracking Variables of Reconstruction \& Security in Post-9/11 Afghanistan," Brookings Institute, January 30, 2012, 29-30, http://www.brookings.edu/ afghanistanindex (20 March 2013). 


\section{Bibliography}

"Operationalization of culture in population-centric operations - the American experience." In Balancing domestic and international security requirements, International Society of Military Sciences. Kingston: Royal Military College of Canada, 2012.

Afghanistan Index: Tracking Variables of Reconstruction \& Security in Post-9/11 Afghanistan. Brookings Institute, 2012.

Army, British. Cultural Orientation Programme In Ghurka Training. British Ministry of Defense, 2013.

Bados, Victor. Operationalization of Culture into Military Operations: Best Practices. Granada: SP TRADOC, 2010.

Commander's Guide to Female Engagement Teams. Handbook In Center for Army's Lessons Learned. Kansas: CALL, 2011.

Comprehensive Approach In NATO A-Z., 2010.

Cordesman, Anthony. The Afghanistan-Pakistan War at the End of 2011: Strategic Failure? Talk Without Hope? Tactical Success? Spend Not Build (And Then Stop Spending)?. Washington: Center for Strategic and International Studies, 2011.

Cultural Awareness Afghanistan Course. British Army ADL, 2012.

Division, Zaytun. Civil-Military Operations Handbook In ROK Peace and Reconstruction Division. MND-NE Iraq, 2006.

Eronen, Oskari. PRT Models in Afghanistan. Approaches to Civil-Military Integration. Kuopio: Crisis Management Center Finland, 2008.

Forte, Maximilian. Canada's Own Human Terrain System: White Situational Awareness Team in Afghanistan. Zero Anthropology, 2008.

Forte, Maximilian. More European Press Coverage of the Human Terrain System. Zero Anthropology portal, 2010.

Hess, Julius. The Operational Relevance of Culture and the Effectiveness of CrossCultural Competence. Empirical Findings from a Panel Study among German Soldiers of the 22nd ISAF contingent In multimedia presentation at the CIMIC Center of Excellence. Enschede, 2012.

MNE 7: Access to Global Commons., 2011.

Multinational Experiment 6 In Multimedia presentation. Oslo: Royal Norwegian Army, 2009. 
Pamplos, Francesco, and Jacinto Pena. Cross-Cultural Awareness: Analytical Concept. Granada: TRADOC Directorate for Research, Doctrine and Materiel, 2010.

Services, Directorate of Educati. British Army Cultural Guidance (Wiltshire, UK: Headquarters Land Forces. Wiltshire, UK: Headquarters Land Forces, 2008.

Trochowska, Kamila. Operationalization of Culture in Contemporary Military Operations. Vol. PhD dissertation. Warsaw: Polish National Defense University, 2013. 